\title{
Arsenic, Fluoride, and Vanadium in surface water (Chasicó Lake, Argentina)
}

\author{
María L. Puntoriero, Alejandra V. Volpedo and Alicia Fernández Cirelli* \\ Facultad de Ciencias Veterinarias, UBA, Centro de Estudios Transdisciplinarios del Agua, Instituto de Investigaciones en Producción Animal (INPA-UBA-CONICET), \\ Buenos Aires, Argentina
}

\section{Edited by:}

Ramanathan Alagappan, Jawahralal

Nehru University, India

Reviewed by:

Marco Petitta, Università di Roma La

Sapienza, Italy

Grzegorz Gzyl, Central Mining

Institute, Poland

*Correspondence:

Alicia Fernández Cirelli, Facultad de Ciencias Veterinarias, UBA, Centro de Estudios Transdisciplinarios del Agua, Instituto de Investigaciones en Producción Animal (INPA-UBA-CONICET), Av. Chorroarín 280, (C1427CWO), Buenos Aires, Argentina e-mail: afcirelli@fvet.uba.ar
Chasicó Lake is the main water body in the southwest of the Chaco-Pampean plain. It shows some differences from the typical Pampean shallow lakes, such as high salinity and high arsenic and fluoride levels. The aim of this paper is to analyze the trace elements [arsenic (As), fluoride $\left(\mathrm{F}^{-}\right)$and vanadium (V)] present in Chasicó Lake. Surface and groundwater were sampled in dry and wet periods, during 2010 and 2011. Fluoride was determined with a selective electrode. As and $V$ were determined by Inductively Coupled Plasma Atomic Emission Spectroscopy (ICP-AES). Significant correlation in surface water was only found for $A s$ and $F^{-}(r=0.978, p<0.01)$. The $A s, F^{-}$and $V$ concentration values were higher and more widely dispersed in surface water than in groundwater, as a consequence of evaporation. The fact that these elements do not correlate in surface water may also indicates that groundwater would not be the main source of origin of As, $\mathrm{F}^{-}$and $\mathrm{V}$ in surface water. The origin of these trace elements is from volcanic glass from Pampean loess. As, $\mathrm{F}^{-}$and $\mathrm{V}$ concentration were higher than in national and international guideline levels for the protection of aquatic biota. Hence, this issue is relevant since the silverside (Odontesthes bonariensis) is the most important commercial species in Chasicó Lake. This fish is both consumed locally and exported to other South-American countries through commercial and sport fishing.

Keywords: arsenic, fluoride, vanadium, surface water, Chasicó Lake, Argentina

\section{INTRODUCTION}

The Chaco-Pampa plain of central Argentina is one of most extended plain regions of the world with high levels of arsenic groundwater, covering around $1 \times 10^{6} \mathrm{~km}^{2}$ (Smedley and Kinniburg, 2002). The plain in the southwest extreme of this region in Buenos Aires Province, is crossed by Ventania orographic system. The presence of arsenic (As) and related elements such as fluoride $\left(\mathrm{F}^{-}\right)$and vanadium $(\mathrm{V})$ have been well documented in groundwater (Paoloni et al., 2009). Nevertheless, studies of their presence in surface water are scarce. Our first findings of the presence of As in surface water in Buenos Aires Province were in the channels and rivers in Samborombón Bay, belonging to the Salado River Basin, where the relationship between surface and groundwater has been determined (Schenone et al., 2007). Rosso et al. (2011a,b) reported high levels of natural contamination with As and other trace metals $\left(\mathrm{F}^{-}\right.$and $\left.\mathrm{V}\right)$ in lotic and lentic ecosystems to the southwest of Buenos Aires Province.

Chasicó Lake is located in the southwest of Buenos Aires Province in Villarino locality and it is the main water body in the southwest of the Chaco-Pampa plain. This is an endorheic system that receives the waters of the Chasicó Stream and drains into the Ventania system. It is placed on a tectonic belt located more than $20 \mathrm{~m}$ below sea level on the southwest slopes of the orographic Ventania system. It extends from a northwest to a southeast direction, parallel to the tectonic pit inside which is located the Colorado River. Chasicó Lake shows some differences from the typical Pampean shallow lakes, namely, its tectonic and eolic origin, greater depth, absence of macrophytes, and high salinity (Table 1). The lake recharge occurs from direct precipitation, groundwater system and surface runoff from a reception basin of $3764 \mathrm{~km}^{2}$ (Bonorino et al., 1989). The area of the Chasicó Lake was $31 \mathrm{~km}^{2}$ in 1963 , it increased to $85 \mathrm{~km}^{2}$ in 2003-2004, and decreased to $50.3 \mathrm{~km}^{2}$ at present (Remes Lenicov and Colautti, 2003). This may be the result of natural periods of flooding and drought, which were reflected in salinity and aquatic biota changes. The average maximum depth of this water body is $16 \mathrm{~m}$.

The fauna in Chasicó Lake is limited due to the chemical composition of the water, with the silverside (Odontesthes bonariensis) being the most commercially relevant species in the Lake. Given its biodiversity and special characteristics, the Lake was declared as "Provincial Natural Reserve of Mixed Defined Purposes" (Provincial Law No. 12.353, 1999). In addition, to the southwest of the Lake there is the Chapalcó watering place, where sport fishing is the main activity. Although the local population in the area has not more than 250 inhabitants (Institute of Statistics and Census of Argentina, 2010 Census), approximately 65000 national and foreign tourists visit the Lake each year during the fishing season. This could be a potential risk to the local population and fishermen that consume fish in this area (Puntoriero et al., 2014). 
Table 1 | pH, Total dissolved Solids (TDS, mg/L) and major ionic concentrations (meq/ L) of some Pampean water bodies.

\begin{tabular}{|c|c|c|c|c|c|c|c|c|c|c|c|}
\hline Waterbodies & pH & TDS & $\mathrm{Na}$ & $\mathbf{K}$ & $\mathrm{Ca}$ & Mg & Cl & $\mathrm{CO}_{3}$ & $\mathrm{HCO}_{3}$ & $\mathrm{SO}_{4}$ & References \\
\hline Chascomús & - & - & 13.4 & 1.7 & 1.4 & 1.7 & 6.5 & 1.0 & 3.4 & 2.7 & Conzonno, 2009 \\
\hline El Burro & 9.4 & 1342.1 & 17.1 & 0.4 & 1.0 & 2.1 & 9.9 & 3.9 & 4.8 & 2.1 & Miretzky et al., 2001 \\
\hline Encadenadas de Chascomús & 8.2 & 2388.4 & 28.37 & 0.82 & 2.7 & 4.77 & 20.5 & 0.87 & 7.48 & 7.8 & Miretzky et al., 2001 \\
\hline La Salada & 10.3 & 999.8 & 14.1 & 0.6 & 0.3 & 0.9 & 7.3 & 4.8 & 3.5 & 0.4 & Miretzky et al., 2001 \\
\hline La Viuda & 9.5 & 1228 & 15.2 & 0.7 & 0.7 & 1.7 & 8.7 & 3.6 & 6.3 & 0.2 & Miretzky et al., 2001 \\
\hline Adela & 8.1 & 1679.5 & 19.8 & 0.5 & 1.9 & 2.9 & 13.2 & 0 & 8.0 & 3.6 & Miretzky et al., 2001 \\
\hline Yalca & - & - & 9.1 & 0.7 & 0.6 & 1.0 & 1.8 & 0.1 & 3.5 & 0.3 & Conzonno, 2009 \\
\hline Carpincho & - & - & 22.7 & 1.3 & 1.2 & 1.4 & 6.8 & 3.7 & 6.3 & 4.2 & Conzonno, 2009 \\
\hline Salada Grande & - & - & 41.3 & 25.1 & 2.5 & 15.1 & 48.9 & 0.7 & 6.7 & 3.1 & Conzonno, 2009 \\
\hline Chasicó & 8.6 & - & - & 3 & 3.2 & 40 & 244.8 & 4.5 & 9.9 & 17.7 & Remes Lenicov and Colautti, 2003 \\
\hline Chasicó & 8.7 & 27100 & 432.5 & 4.9 & 2.8 & 49.4 & 344.9 & - & 140.2 & 0.9 & This paper (2010) \\
\hline Chasicó & 8.6 & 31130 & 529.9 & 9.43 & 3.0 & 57.0 & 685.1 & 14.36 & 19.9 & 0.8 & This paper (2011) \\
\hline
\end{tabular}

The aim of this paper is to analyze the trace elements (As, $\mathrm{F}^{-}$, and V) present in Chasicó Lake, which is the most representative lentic body in southwest of Buenos Aires Province.

\section{MATERIALS AND METHODS}

Water was sampled from the surface of the pelagic zone of Chasicó Lake and Chasicó Stream, in dry (March) and wet (August) periods, during 2010 and 2011 (Figure 1). Precipitation and temperature values are shown for each period in Table 2. Groundwater samples were collected from wells (average depth of $7-15 \mathrm{~m}$, depending on the specific construction characteristics) used for human consumption in the Chasicó locality (Figure 1). Samples were taken by triplicate, filtered through a $0.45 \mathrm{~mm}$ acetate cellulose membrane (Micro Separations Inc., MSI), and stored in polyethylene bottles. Samples were acidified to preserve the analytes in solution with $\mathrm{HNO}_{3} \quad 0.2 \%$ $\mathrm{v} / \mathrm{v}$ for the measurement of As and V. At each sampling site, water conductivity $\left(\mathrm{mS} \mathrm{cm} \mathrm{cm}^{-1}\right)$ and $\mathrm{pH}$ were measured in situ. Fluoride was determined by the electrometric method with a selective electrode. As and $\mathrm{V}$ were determined by Inductively Coupled Plasma Atomic Emission Spectroscopy (ICP-AES) using a Perkin Elmer Optima 2000 DV. The ICP-AES detection limits for the elements analyzed were for As: $10 \mu \mathrm{g} / \mathrm{L}$ and V: $8 \mu \mathrm{g} / \mathrm{L}$. Statistical and correlation analysis (Pearson) were applied to asses possible interrelations among $\mathrm{As}, \mathrm{F}^{-}$and $\mathrm{V}$, in surface and groundwater.

\section{RESULTS}

As, $\mathrm{F}^{-}$and $\mathrm{V}$ concentrations were measured in Chasicó Lake, Chasicó Stream and groundwater of Chasicó locality, in dry and wet periods (Tables 3,4). Recorded $\mathrm{pH}$ values corresponded to an alkaline type of water, in Chasicó Lake and Chasicó Stream. The average values of conductivity in Chasicó Lake were higher than Chasicó Stream. These could be associated with climatic factors such as precipitation and evaporation. In particular, the lower conductivity recorded in the wet period, when rainfall was higher (289 mm accumulated rainfall in February-March 2010, according to the National Meteorological Service), may be due to a dilution effect.

As, $\mathrm{F}^{-}$and $\mathrm{V}$ concentrations were higher in the dry period compared to the wet period in both water bodies, while the $\mathrm{V}$ presented greatest differences in both periods. Significant correlations were found as expected in groundwater between: As and $F^{-}(r=0.972, p<0.01)$, As and $V(r=0.89, p<0.01)$ and $V$ and $F^{-}(r=0.98, p<0.01)$, while in surface water it was only found for As and $F^{-}(r=0.978, p<0.01)$ (Figures 2-5). The As, $\mathrm{F}^{-}$and $\mathrm{V}$ concentration values were higher and more widely dispersed in surface water than in groundwater, as a consequence of evaporation. The fact that these elements do not correlate in surface water (As and $V ; p>0.05) ;\left(F^{-}\right.$and $\left.V ; p>0.05\right)$ may also indicate a different origin.

\section{DISCUSSION AND CONCLUSIONS}

In all cases As concentrations found in Chasicó Lake were higher than the guideline levels for the protection of the national aquatic biota on the surface water $(0.05 \mathrm{mg} / \mathrm{L}$, Hazardous Waste Act, Law 24051). According to international organizations (CCME), these levels widely exceeded the permitted level of $0.005 \mathrm{mg} / \mathrm{L}$ for freshwater. Regarding $\mathrm{F}^{-}$, there are national guideline levels only for surface saltwater $(1.4 \mathrm{mg} / \mathrm{L})$ and according to the CCME the permitted level for the protection of aquatic biota is $0.12 \mathrm{mg} / \mathrm{L}$, which in all cases are higher. Regarding V, at the national level the values reported in this paper were exceeded during the dry period $(0.1 \mathrm{mg} / \mathrm{L}$ for surface freshwater, Hazardous Waste Act) whereas no limits have been set so far internationally for $\mathrm{V}$ for the protection of aquatic biota. 


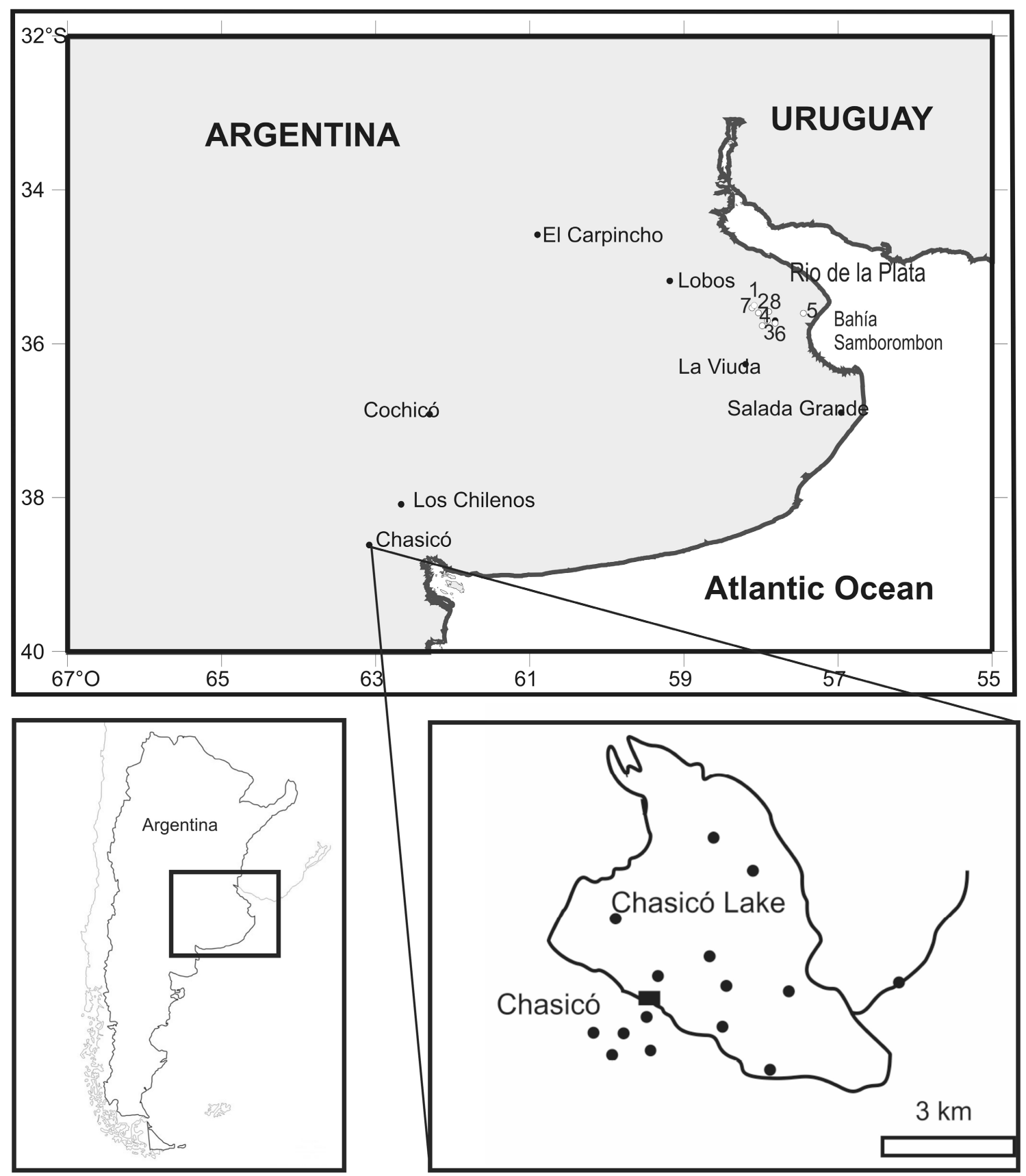

FIGURE 1 | Sampling sites of Chasicó and other waterbodies of Pampean Plain. 1, Adela; 2, Chascomús; 3, Chis-Chis; 4, del Burro; 5, La Salada; 6, La Segunda; 7, Vitel; 8, Yalca.

Table 2 | Precipitation $(\mathrm{mm})$ and temperature $\left({ }^{\circ} \mathrm{C}\right)$ values, during dry (March) and wet (August) period.

\begin{tabular}{cccccc}
\hline & \multicolumn{2}{c}{ Wet period (March) } & & \multicolumn{2}{c}{ Dry period (August) } \\
\cline { 2 - 3 } \cline { 5 - 6 } & $\begin{array}{c}\text { Temperature } \\
\left({ }^{\circ} \mathbf{C}\right)\end{array}$ & $\begin{array}{c}\text { Precipitations } \\
(\mathbf{m m})\end{array}$ & & $\begin{array}{c}\text { Temperature } \\
\left({ }^{\circ} \mathbf{C}\right)\end{array}$ & $\begin{array}{c}\text { Precipitations } \\
(\mathbf{m m})\end{array}$ \\
\hline 2010 & 26.6 & 120.8 & & 16.3 & 3.9 \\
2011 & 27.3 & 109.3 & & 15.9 & 3.7
\end{tabular}

Chasicó Lake is a water body whose characteristics differ from those of the Pampean lakes, in which groundwater is the base flow (Fernández Cirelli and Miretzky, 2004). The presence of As, $\mathrm{F}^{-}$and $\mathrm{V}$ in Chasicó Lake is not the result of anthropic pollution since there are not sources of industrial pollution, so the origin of these trace elements is from volcanic glass from Pampean loess (Teruggi, 1957). It cannot be assured that these elements are derived from groundwater since no connection between these two water sources has been found. 
Table 3 | As, $\mathrm{F}^{-}$and $\mathbf{V}$ concentrations (minimum- maximum values), conductivity and $\mathrm{pH}$ values, in surface water of Chasicó Lake and Chasicó Stream, during wet and dry period.

\begin{tabular}{lccccc}
\hline & Wet period & Dry period & & Wet period & Dry period \\
\cline { 2 - 3 } \cline { 5 - 6 } & \multicolumn{2}{c}{ Chasicó Lake } & & \multicolumn{2}{c}{ Chasicó Stream } \\
\hline $\mathrm{pH}$ & $8.61-8.69$ & $8.7-8.75$ & & $8.62-8.7$ & $8.75-8.8$ \\
Cond. $(\mathrm{ms} / \mathrm{cm})$ & $16.3-20.4$ & $38.7-38.8$ & & $12.5-13.7$ & $18.8-19.61$ \\
As $(\mathrm{mg} / \mathrm{L})$ & $0.195-0.315$ & $0.058-0.413$ & & $0.096-0.105$ & $0.148-0.172$ \\
$\mathrm{~F}(\mathrm{mg} / \mathrm{L})$ & $6.74-8.5$ & $8.47-8.54$ & & $6.74-6.8$ & $6.77-7.2$ \\
$\mathrm{~V}(\mathrm{mg} / \mathrm{L})$ & $0.044-0.086$ & $0.096-0.366$ & & $0.068-0.094$ & $0.184-0.252$ \\
\hline
\end{tabular}

Guideline levels for the protection aquatic biota: $A s, 0.05 \mathrm{mg} / \mathrm{L}$ (Hazardous Waste Act); $0.005 \mathrm{mg} / \mathrm{l}$ (CCME). F, $1.4 \mathrm{mg} / \mathrm{L}$ (Hazardous Waste Act); $0.12 \mathrm{mg} / \mathrm{l}$ (CCME). V, $0.1 \mathrm{mg} / \mathrm{l}$ (Hazardous Waste Act).

Table 4 | As, $F^{-}$and $\mathbf{V}$ concentrations (minimum- maximum values), conductivity and pH values, in groundwater in Chasicó locality, during wet and dry period.

\begin{tabular}{lcc}
\hline & Wet period & Dry period \\
\cline { 2 - 3 } & \multicolumn{2}{c}{ Chasicó locality } \\
\hline $\mathrm{pH}$ & $7.38-7.94$ & $7.49-7.74$ \\
Cond. $(\mathrm{ms} / \mathrm{cm})$ & $1.04-3.58$ & $0.99-3.13$ \\
As $(\mathrm{mg} / \mathrm{L})$ & $0.092-0.095$ & $0.024-0.166$ \\
$\mathrm{~F}(\mathrm{mg} / \mathrm{L})$ & $1.98-2.02$ & $0.4-3.47$ \\
$\mathrm{~V}(\mathrm{mg} / \mathrm{L})$ & $0.269-0.278$ & $0.141-0.556$
\end{tabular}

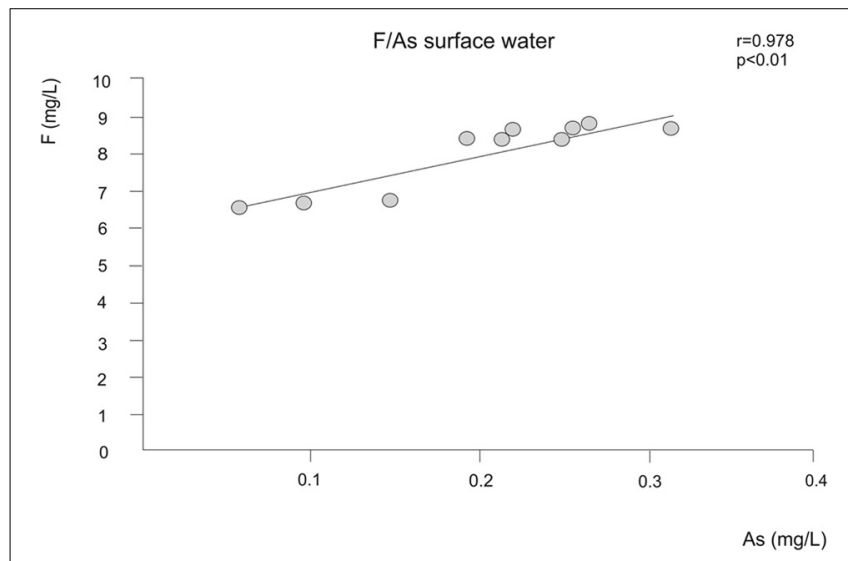

FIGURE 2 | Correlations between As and $F^{-}$in surface water.

One of the factors controlling groundwater composition is the cation exchange process, but this was not demonstrated in surface water. The chemical composition of the surface water of Chasicó Lake differed significantly from that groundwater, suggests that the latter is not the main source of water of the former, according to (Puntoriero et al., 2014). Weathering of sediments of Chasicó Lake and the evaporation-crystallization process could be one of the factors controlling the chemical composition of the water of the Lake (Volpedo and Fernández Cirelli, 2013). Further studies

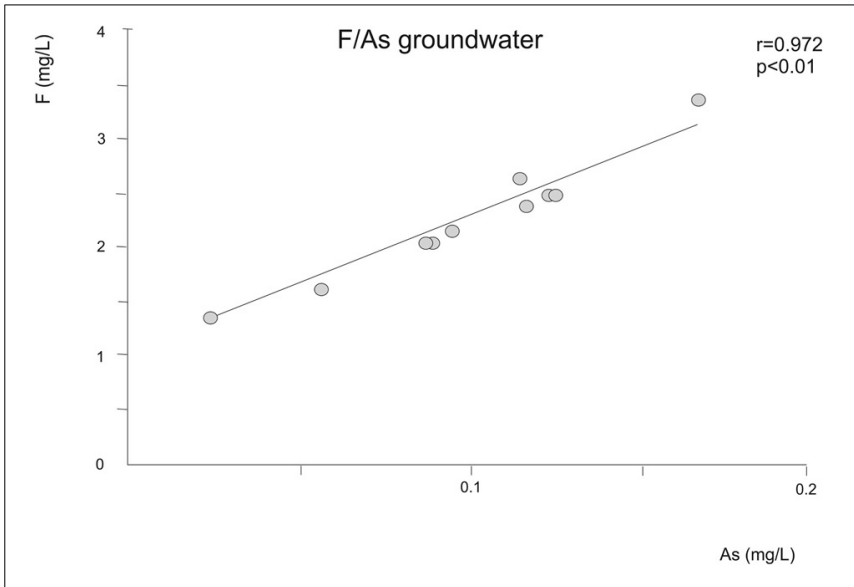

FIGURE 3 | Correlations between As and $\mathrm{F}^{-}$in groundwater.
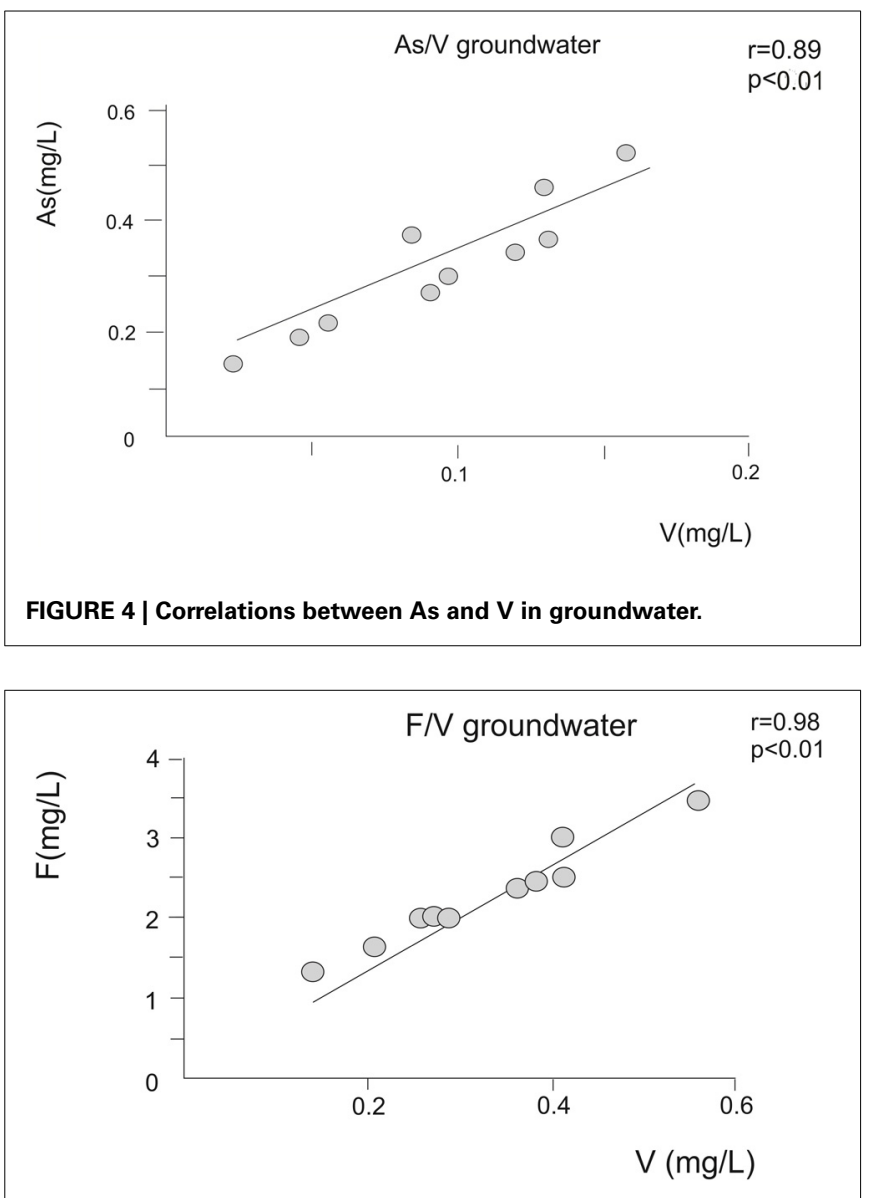

FIGURE 5 | Correlations between $\mathrm{F}^{-}$and $\mathrm{V}$ in groundwater.

are required in order to analyze the geochemical processes that determine the chemical composition of the Chasicó Lake.

In comparison with other water bodies worldwide, Chasicó Lake shows higher levels of As and V than lakes in other continents. However, $\mathrm{F}^{-}$concentrations reported in other continents, were higher than in Chasicó Lake (Table 5). Surface water bodies 
Table 5 | Arsenic (As), fluoride $\left(\mathrm{F}^{-}\right)$, and vanadium (V) concentrations (minimum-maximum values in $\mathrm{mg} / \mathrm{L}$ ) in surface water of different water bodies of the world.

\begin{tabular}{|c|c|c|c|c|c|}
\hline Water bodies & Cond $(\mathrm{ms} / \mathrm{cm})$ & As & $F^{-}$ & $\boldsymbol{V}$ & References \\
\hline Tibet Lakes (Asia) & $0.0145-3.7$ & $0.002-0.252$ & - & & Li et al., 2013 \\
\hline Manchar Lake (Asia) & $3.87-9.21$ & $0.035-0.157$ & - & & Arain et al., 2009 \\
\hline Bogonia Lake (África) & $50.7-81.5$ & $0.018-0.132$ & 530-1310 & & Jirsa et al., 2013 \\
\hline Naburu Lake (África) & $23.1-96.2$ & $0.009-0.103$ & $500-1370$ & & Jirsa et al., 2013 \\
\hline Rift Valley Lakes (África) & - & - & $1-264$ & & Teckle-Haimanot et al., 2006 \\
\hline East African Lakes & $0.001-0.014$ & & $28.5-437$ & & Kilham and Hecky, 1973 \\
\hline Swedish Lakes (Europe) & - & $0.00005-0.0013$ & & $0.00008-0.0018$ & Wällsted et al., 2010 \\
\hline Golf courses Lakes (USA) & - & $0.001-0.124$ & & & Pichler et al., 2008 \\
\hline Pampa plain rivers (Argentina) & $0.001-0.952$ & $0.055-0.198$ & & & Rosso et al., 2011a \\
\hline Pampa plain rivers (Argentina) & $0.001-0.952$ & & $0.15-1.64$ & & Rosso et al., 2011b \\
\hline
\end{tabular}

with high conductivity have a tendency to increase F and As levels, in the dry period, probably due to the presence of competing ions (as $\mathrm{HCO}_{3}$ and $\mathrm{PO}_{4}$ ) that facilitate the desorption of these trace elements (Smedley and Kinniburg, 2002).

In addition, it is important to analyze As, $\mathrm{F}^{-}$and $\mathrm{V}$ concentrations found in Chasicó lake's fish because it could be a potential risk to the local population and fishermen that consume fish in this area (Puntoriero et al., 2014), so it should be further studied.

\section{REFERENCES}

Arain, M. B., Kazi, T. G., Baig, J. A., Jamali, M. K., Afridi, H. I., Shah, A. Q., et al. (2009). Determination of arsenic levels in lake water, sediment, and foodstuff from selected area of Sindh, Pakistan: estimation of daily dietary intake. Food Chem. Toxicol. 47, 242-248. doi: 10.1016/j.fct.2008. 11.009

Bonorino, A., Ruggiero, E., and Mariño, E. (1989). Caracterización hidrogeológica de la cuenca del arroyo Chasicó. Provincia de Buenos Aires. Comisión de Investigaciones Científicas 44, 1-39.

Canadian Council of Ministers of Environment. (CCME) (2002). "Canadian water quality guidelines for protection of aquatic life: Inorganic fluorides," in Canadian Environmental Quality Guidelines, 1999, (Winnipeg: Canadian Council of Ministers of the Environment), 1-4.

Conzonno, V. H. (2009). Limnología Química. La Plata: Editorial de la Universidad Nacional de La Plata.

Fernández Cirelli, A., and Miretzky, P. (2004). Ionic relations: a tool for studying hydrogeochemical processes in Pampean shallow lakes (Buenos Aires, Argentina). Quatern. Int. 114, 113-121. doi: 10.1016/S1040-6182(03)00046-6

Galindo, G., Herrero, M. A., Korol, S., and Fernández Cirelli A. (2004). Water resources in the Salado River drainage basin, Buenos Aires, Argentina: chemical and microbiological characteristics. Int. Water Res. Assoc. 29, 81-90. doi: $10.1080 / 02508060408691751$

Jirsa, F., Gruber, M., Stojanovic, A., Odour Omondi, S., Mader, D., Körner, W., et al. (2013). Major and trace element geochemistry of Lake Bogoria and Lake Nakuru, Kenya, during extreme draught. Chem. Erde 73, 275-282. doi: 10.1016/ j.chemer.2012.09.001

Kilham, P., and Hecky, R. E. (1973). Fluoride: Geochemical and ecological significance in east African waters and sediments. Limnol. Oceanogr. 18, 932-945.

Law, 24051. (1992). Ley Nacional de Residuos Peligrosos (Regime for hazardous wastes). Secretaría de Ambiente y Desarrollo Sustentable. Available online at: http://www2.medioambiente.gov.ar/mlegal/residuos/ley24051.htm

Li, S., Wang, M., Yang, Q., Wang, H., Zhu, J., Zheng, B., et al. (2013). Enrichment of arsenic in surface water, stream sediments and soils in Tibet. J. Geochem. Explor. 87, 638-639. doi: 10.1016/j.gexplo.2012.08.020

Miretzky, P., Conzonno, V. H., and Fernández Cirelli, A. (2001). Geochemical mechanism controlling pampasic ponds hydrochemistry, Salado River drainage basin, Argentina. Revista Brasileira de Recursos Hidricos 6, 29-39.

Paoloni, J. D., Sequeira, M. E., Espósito, M. E., Fiorentino, C. E., and Blanco, M. C. (2009). Arsenic in water resources of the Southern Pampa Plains, Argentina. J. Environ. Public Health 2009:216470. doi: 10.1155/2009/ 216470
Pichler, T., Brinkmann, R., and Scarzella, G. I. (2008). Arsenic abundance and variation in golf course lakes. Sci. Total Environ. 394, 313-320. doi: 10.1016/j.scitotenv.2008.01.046

Puntoriero, M. L., Volpedo, A., and Fernández Cirelli, A. (2014). Riesgo para la población rural en zonas con alto contenido de arsénico en agua. Acta Toxicol. Argentina 22, 1-15.

Remes Lenicov, M. and Colautti, D. (2003). Estudio de la laguna Chasicó (Pdo. de Villarino y Puán). En: Campaña de relevamientos limnológicos e ictiológicos. Subsecretaría de Actividades Pesqueras, MAA Provincia de Buenos Aires, Informe Técnico $\mathrm{n}^{\circ}$ 56: 1-25.

Rosso, J. J., Puntoriero, M. L., Troncoso, J. J., Volpedo, A. V., and Fernández Cirelli, A. (2011a). Occurrence of Fluoride in Arsenic-rich Surface Waters: a Case Study in the Pampa Plain, Argentina. Bull. Environ. Contam. Toxicol. 87, 409-413. doi 10.1007/s00128-011-0358-0

Rosso, J. J., Troncoso, J. J., and Fernández Cirelli, A. (2011b). Geographic Distribution of Arsenic and trace metals in lotic ecosystems of the Pampa Plain, Argentina. Bull. Environ. Contam. Toxicol. 86, 129-132. doi: 10.1007/s00128010-0177-8

Schenone, N., Volpedo, A. V., and Fernández Cirelli, A. (2007). Trace metal contents in water and sediments in Samborombon Bay wetland, Argentina. Wetlands Ecol. Manage. 15, 303-310. doi: 10.1007/s11273-006-9030-6

Smedley, P., and Kinniburg, D. (2002). A review of the source, behaviour and distribution of arsenic in natural waters. Appl. Geochem. 17, 517-568. doi: 10.1016/S0883-2927(02)00018-5

Teckle-Haimanot, R., Melaku, Z., Kloos, H., Reimann, C., Fantaye, W., Zerihun, L., et al. (2006). The geographic distribution of fluoride in surface and groundwater in Ethiopia with an emphasis on the Rift Valley. Sci. Total Environ. 367, 182-190. doi: 10.1016/j.scitotenv.2005.11.003

Teruggi, M. E. (1957). The nature and origin of Argentina Loess. J. Sediment. Petrol. $27,322-332$.

Volpedo, A., and Fernández Cirelli, A. (2013). El Lago Chasicó: similitudes y diferencias con las lagunas pampásicas. augmdomus 5, 1-18.

Wällsted, T., Björkvald, L., and Gustafsson, J. P. (2010). Increasing concentrations of arsenic and vanadium in (southern) Swedish streams. Appl. Geochem. 25, $1162-1175$.

Conflict of Interest Statement: The authors declare that the research was conducted in the absence of any commercial or financial relationships that could be construed as a potential conflict of interest.

Received: 28 March 2014; accepted: 03 June 2014; published online: 20 June 2014. Citation: Puntoriero ML, Volpedo AV and Fernández Cirelli A (2014) Arsenic, Fluoride, and Vanadium in surface water (Chasicó Lake, Argentina). Front. Environ. Sci. 2:23. doi: 10.3389/fenvs.2014.00023

This article was submitted to Groundwater Resources and Management, a section of the journal Frontiers in Environmental Science.

Copyright (c) 2014 Puntoriero, Volpedo and Fernández Cirelli. This is an openaccess article distributed under the terms of the Creative Commons Attribution License (CC BY). The use, distribution or reproduction in other forums is permitted, provided the original author (s) or licensor are credited and that the original publication in this journal is cited, in accordance with accepted academic practice. No use, distribution or reproduction is permitted which does not comply with these terms. 